\title{
The impact of Craigslist's entry on competing employment websites
}

Vera Brenčič

Correspondence: vbrencic@ualberta.ca Department of Economics, University of Alberta, 8-14 Tory Building, Edmonton, Alberta T6G 2H4, Canada

\begin{abstract}
Craigslist, a website that hosts job- and help-wanted ads, expanded rapidly across the states in the USA over a very short period of time, thereby changing abruptly the market structure faced by competing employment websites. We exploit this abrupt change to evaluate its impact on competing websites' online traffic and pricing. We find that Craigslist's entry was associated with a decrease in the number of visitors that an average competing employment website attracted and with a decrease in the number of pages an average visitor reviewed during a typical visit. We also find that employment websites lowered some of the fees they charged their users. Overall, these findings offer one explanation for why Craigslist, despite its popularity, had little effect on the unemployment rate in the labor markets it entered: the entry of Craigslist cannibalized online traffic at competing employment websites.

JEL Classification: J20, L10, L86

Keywords: Entry response, Employment website, Craigslist
\end{abstract}

\section{Introduction}

By reducing the costs of disseminating and acquiring information, the Internet brought the possibility of substantially reduced search frictions and improved functioning of the labor market (Autor, 2001). Kroft and Pope (2014), however, find that the entry into local labor markets of Craigslist, a popular website that hosts job ads, had no effect on unemployment rates in these markets. While the authors speculate (p. 298) that Craigslist's effect might have been attenuated by the fact that Craigslist provided a service that was already offered by existing competing websites, the authors do not test empirically their hypothesis. ${ }^{1,2}$

In this paper, we provide empirical evidence of the effects of Craigslist's entry on competing employment websites. We use a panel of websites hosting job boards and resume banks from 2005 to 2007, a period of rapid expansion of Craigslist across the states in the USA. Similar to Kroft and Pope (2014) and Chan and Ghose (2014), we argue that the sudden rise in popularity of Craigslist during this period changed abruptly the market structure faced by competing employment websites. We exploit this abrupt change to evaluate its impact on competing websites' online traffic and pricing. Our analysis draws on a comparison across employment websites that faced varying degrees of competition from Craigslist.

(C) 2016 The Author(s). Open Access This article is distributed under the terms of the Creative Commons Attribution 4.0 International License (http://creativecommons.org/licenses/by/4.0/), which permits unrestricted use, distribution, and reproduction in any medium, provided you give appropriate credit to the original author(s) and the source, provide a link to the Creative Commons license, and indicate if changes were made. 
We measure exposure to Craigslist with the number of job-related postings on Craigslist and the number of years since Craigslist's entry in the market in which competing websites operate. We code employment websites that served a particular US state as competing with Craigslist if Craigslist entered at least one city in that state. For websites serving the entire USA, we consider two treatments. In the first treatment, these websites are coded as competing with Craigslist once Craigslist entered its first city. In the second, these websites are coded as not competing with Craigslist. To control for heterogeneity across employment websites, we control for time-varying website-level attributes (e.g., the number of different types of postings that the websites hosted, services offered by the websites, age) and add website-level fixed effects. We also include controls for attributes of the markets that employment websites served (e.g., unemployment rate, job creation rate, educational attainment, Internet access by residents, population size and density, fraction of workers employed in information sector).

We find that Craigslist's entry into the markets of competing employment websites was associated with a decline in both the number of visitors that an average competing website attracted and the number of pages an average visitor reviewed while on these websites. For example, the average number of visitors to a competing employment website declined by 3740 whereas the number of page views per visitor to a competing website declined by 1 for every additional 100 job-related postings that Craigslist hosted in the competing website's market. We also find that employment websites reacted to increased competition for online users prompted by Craigslist's entry by adjusting some of the fees they charged their users. Specifically, we document a decline in the average fees that the websites charged to employers and an increase in the likelihood that job searchers and employers were offered a discount as Craigslist became more entrenched in the markets of competing employment websites.

These findings are consistent with the view that the absence of beneficial effects of Craigslist's entry into local labor markets in the USA documented by Kroft and Pope (2014) can be attributed in part to a business-stealing effect. That is, Craigslist's entry into local labor markets in the USA resulted in no distinguishable change in the unemployment rate in these markets because it cannibalized online traffic at competing websites.

The paper's findings also suggest that Craigslist's entry might have had mixed welfare effects. In other words, while increased competition prompted by Craigslist's entry benefitted online users by resulting in lower prices at competing employment websites, the entry also reduced online traffic at these websites. Because the gains of visiting these websites increase the more these websites get used by other participants (a feature that is inherent to platforms, like employment websites, that operate in multisided markets), Craigslist's entry rendered these websites less useful to their potential users by reducing their online traffic. ${ }^{3}$

Our findings contribute to three areas of research. First, our focus on interactions between employment websites complements studies that analyze data from a single employment website. These studies examine how employers and job searchers search with the help of these websites (with data from Monster in Brenčič and Norris (2010), Snagajob in Kudlyak et al. (2013), and CareerBuilder in Marinescu and Rathelot (2014)) and the implications of their use for search outcomes (with data from oDesk in Stanton 
and Thomas (2015), Agrawal et al. (2013), Pallais (2014), and Horton (2016)). Unlike these studies that focus on the users' experience with a single employment website, our focus is on the market for these websites.

Second, our findings contribute to other studies on the effects of Craigslist's expansion in the USA. In addition to Kroft and Pope (2014), a study by Seamans and Zhu (2014) is closely related to our paper because of its focus on the effect of Craigslist's entry on pricing (together with circulation and provision of content) in the market for newspapers. Chan and Ghose (2014) focus on the effect of Craigslist's entry on new HIV cases, while Gurun and Butler (2012) on the use of slant by local newspapers. Unlike these papers that focus on how the diffusion of the Internet-as represented by entry of an online intermediary-affects activities offline (e.g., decision-making by newspaper, sexual behavior), our study examines Craigslist's effects on activities online (i.e., online traffic at and pricing by competing online intermediaries).

Finally, our findings contribute to the literature on the reactions of incumbents to new entrants and, specifically, to studies that focus on reactions by platforms in multisided markets to changes in market structure (Jin and Rysman (2015), Chandra and Collard-Wexler (2009), Fan (2013), and Seamans and Zhu (2014)). While in our study a change in market structure is triggered by the entry of a new competitor as in Seamans and Zhu, in other studies, it occurs as a result of mergers (Chandra and Collard-Wexler and Fan) or a change in the definition of a geographical market (Jin and Rysman). The distinguishing features of our analysis are its focus on (a) online platforms in the labor market and (b) joint examination of the effect of a change in market structure prompted by Craigslist's entry on employment websites' traffic, prices, use of discounts, and use of bundling of services the websites offer their users. ${ }^{4}$

We start with a description of the data and our empirical approach in Section 2. In Sections 3 and 4, we review our results. In Section 5, we review evidence from two robustness checks that include an alternative measure of Craigslist's presence in the markets of competing websites and an alternative sample period. Concluding remarks are delegated to Section 6.

\section{Description of data and empirical approach}

We use data from Weddle's two biennial Guides to Employment Web Sites (Weddle, 2005, 2007). ${ }^{5}$ In 2005 and 2007, a representative sample of 350 employment websites was surveyed. We drop from the sample websites that served markets outside of the USA, websites for which information on key variables was not available, and-given our inclusion of website-level fixed effects-websites for which data are available in only one survey. As a result of these restrictions, our sample over-represents large employment websites (i.e., websites that attract a large number of visitors and host a large number of postings) and those that serve the entire US market. ${ }^{6}$

For each website, we use information about the number of visitors and the number of page views per visitor in a typical month as proxies for how successful the website was in facilitating the exchange of information between its users. We also observe when and whether a website served a state or the entire USA. Regional websites served between 7 and 15 different US states in the samples that we use to get our estimates. We use this information in order to identify whether a website was exposed to Craigslist's entry during the sample period. We collected data on the cities entered and the 
corresponding years of entry from Craigslist's website (www.craigslist.org). We supplemented this information with information from archived Craigslist webpages (www.archive.org) as in Seamans and Zhu (2014).

We code a website that served a particular US state as competing with Craigslist if Craigslist entered at least one city in that state. ${ }^{7}$ For websites that served the entire USA, we consider two different treatments. We either code the websites as competing with Craigslist once Craigslist entered its first city or we code them as not competing with Craigslist. ${ }^{8}$ The first treatment might be preferred on two counts. First, national websites facilitate search across states in a similar way as Craigslist. For example, while national websites allow their users to search postings by state using a search engine, Craigslist offers links that direct users to postings on Craigslist's websites that serve individual US states (www.craigslist.ca/about/sites\#US). Second, evidence suggests that Craigslist's popularity rivaled that of national websites like Monster, CareerBuilder, and Yahoo! Hotjobs at the Metropolitan Statistical Area (MSA) level. ${ }^{9}$

Our focus on Craigslist is motivated by Kroft and Pope (2014) and Chan and Ghose (2014) who document that Craigslist experienced a rapid increase in popularity across different states in the USA over a very short period of time. Craigslist started in 1995 as an email distribution list and was launched as a website in 1996 for the San Francisco area. The company was incorporated in 1999 and began to expand across the USA with most of its expansion taking place over a very short period of a couple of years. In contrast, other well-known employment websites experienced increases in popularity at much steadier paces (Kroft and Pope, p. 269). This feature of Craigslist's entry ensures large spatial and temporal variation in the market structure that existing competing employment websites faced.

Our empirical approach requires the random entry of Craigslist. Both Kroft and Pope (2014) and Chan and Ghose (2014) find that Craigslist's entry is poorly explained by attributes of the markets it entered. The authors interpret this finding as supporting the view that Craigslist's entry was akin to a random event. Chan and Ghose, for example, describe geographic and temporal variation in Craigslist's entry as a natural experiment. Kroft and Pope also note that Craigslist's entry into a market was not based on expected profits because of the nonprofit nature of the website. If Craigslist's entry was not random, however, the direction of the bias for our estimates is unclear. Kroft and Pope (p. 274) mention that Craigslist enters a new city on the basis of the number of requests that they receive. If most requests are received from markets that are not serviced by other employment websites, then Craigslist's entry into these under-served areas is expected to have a smaller effect on competing websites. ${ }^{10}$

Our focus on the period from 2005 through 2007 is motivated, on the one hand, by the fact that Craigslist experienced a dramatic upsurge in popularity in 2005. Prior to 2005, the number of postings hosted by Craigslist was relatively small (Kroft and Pope, 2014). ${ }^{11}$ On the other hand, Weddle's surveys conducted after 2007 restricted data collection to only 100 websites thereby changing the representativeness of our sample.

Three other comments about our sample period are worth mentioning. First, given that the sample of websites that were surveyed changed over time, the expansion of the sample would result in an unbalanced panel of websites. This would lead to a concern that our estimates are affected by the change in the composition of websites over time. Second, our restriction to a short time period makes our analysis less susceptible to 
omitted variable bias due to shocks that might have occurred in the market of employment websites. Finally, our restriction makes the time frame of our analysis similar to that of Kroft and Pope (2014). This similarity matters given our interest in providing an explanation for Kroft and Pope's null result.

We regressed either the number of visitors or the number of page views per visitor to website $i$ on a variable that measures the presence of Craigslist in each website's market:

online traffic $\mathrm{it}_{\mathrm{it}}=\alpha_{0}+\alpha_{1}$ Craigslist presence $_{\mathrm{it}}+\beta X_{i t}+\delta_{i}+\eta_{t}+\varepsilon_{\mathrm{it}}$

Craigslist's presence is measured in one of two ways. First, we include the number of years since Craigslist's entry. Second, we include the number of help- and job-wanted postings hosted by Craigslist in the market in which the competing website operates. ${ }^{12}$ In this latter case, we also control for all other postings on Craigslist to account for heterogeneity in Craigslist's popularity across the markets. These other types of postings include personals, "for sale" ads, ads related to housing, and ads related to community events. In all specifications, we cluster errors at the level of the market (state or the entire USA) to allow for autocorrelation.

Whereas Craigslist websites were nearly identical across the different markets (Seamans and Zhu (2014, p. 480)), competing websites from the Guides were not. This heterogeneity might affect our dependent variables, i.e., how much information is acquired on the websites. For this reason, we added controls $\left(X_{i t}\right)$ for the number of different types of postings that the websites hosted, the complementary services offered by the websites (e.g., email alerts of good matches, availability of career information), the number of job and $\mathrm{CV}$ postings on a website, whether the website was national, the age of the website (and its square) which we define as the difference between the year in the sample and the year the website was founded, and the receipt of Weddle's User's Choice Award as a time-varying proxy for quality.

Because all specifications include website-level fixed effects $\left(\delta_{i}\right)$, we exploit withinwebsite variation to identify effects of Craigslist's entry in the websites' markets. To account for time-varying factors specific to a website's market, we include a year dummy $\left(\eta_{t}\right)$, the job creation rate and unemployment rates, \% of residents with Internet access, ${ }^{13} \%$ of residents with a college degree, \% of workers employed in the information industry, log population, and population density in the market served by each website. ${ }^{14}$ Similar to Kroft and Pope (2014), these controls aim to account for the way the states might have changed technologically and for economic shocks that affected differently states that differed in size.

Table 1 reports summary statistics. ${ }^{15}$ An average website in our sample hosted about 1,081,600 visitors in a typical month, 41,275 job postings, and 361,729 CVs. An average visitor reviewed about 20 pages during a typical visit. Both measures of online traffic increased in 2007/2008 compared to 2005/2006 (top row in Table 2); the number of monthly visitors increased by $33 \%$, on average, while the number of page views per visitor increased by $116 \%$. The average fees that the websites charged their users were about $\$ 4$ per day per job posting, $\$ 0.3$ per day per $C V$ posting, and $\$ 266$ per month for access to CVs. Free access to CVs was offered to employers who paid a fee for posting a job ad by $25 \%$ of the websites. Employers and job searchers, respectively, were offered a discount of 42 and $2 \%$ by the websites. 
Table 1 Summary statistics

\begin{tabular}{|c|c|c|}
\hline \multirow[t]{2}{*}{ Sample: } & \multicolumn{2}{|c|}{ A panel of employment websites (2005/06-2007/08) } \\
\hline & $\overline{M e a n}$ & SD \\
\hline \multicolumn{3}{|l|}{ Website-level attributes } \\
\hline \# of visitors (in 100,000 ) in a month & 10.816 & 28.630 \\
\hline \# of page views per visit & 19.634 & 54.645 \\
\hline Job posting fee per day of posting & 3.617 & 2.909 \\
\hline CV posting fee per day of posting & 0.003 & 0.020 \\
\hline CV access fee per month of access & 266.069 & 300.079 \\
\hline Free access to CVs with purchase of job ad & 0.251 & 0.434 \\
\hline Discount offered to employers & 0.419 & 0.495 \\
\hline Discount offered to job searchers & 0.019 & 0.139 \\
\hline Age of website & 7.245 & 2.893 \\
\hline Receipt of Weddle's choice award & 0.027 & 0.164 \\
\hline General website & 0.018 & 0.135 \\
\hline \# of job categories on website & 2.429 & 1.138 \\
\hline \# of CV categories on website & 1.594 & 1.218 \\
\hline National website & 0.649 & 0.478 \\
\hline Career info offered & 0.931 & 0.253 \\
\hline Match notification offered & 0.800 & 0.401 \\
\hline \# of job postings & 41,275 & 174,635 \\
\hline \# of CV postings & 361,729 & $1,398,824$ \\
\hline \multicolumn{3}{|l|}{ Market-level attributes } \\
\hline Residents with internet access (in \%) & 67.934 & 2.513 \\
\hline Log population & 18.327 & 1.718 \\
\hline Population density & 162.073 & 186.704 \\
\hline Residents with college degree (in \%) & 27.958 & 2.534 \\
\hline Employment in information sector (in \%) & 2.266 & 0.355 \\
\hline Unemployment rate & 4.872 & 0.447 \\
\hline Job creation rate & 15.730 & 1.113 \\
\hline \multicolumn{3}{|l|}{ Craigslist exposure } \\
\hline Job postings on Craigslist (in 1000) ${ }^{a}$ & 909.443 & 839.953 \\
\hline Job postings on Craigslist (in 1000) & 5.743 & 13.434 \\
\hline Years of Craigslist's presence ${ }^{a}$ & 8.349 & 2.933 \\
\hline Years of Craigslist's presence ${ }^{b}$ & 1.560 & 2.828 \\
\hline
\end{tabular}

${ }^{a}$ National websites compete with Craigslist

${ }^{b}$ National websites do not compete with Craigslist

According to Table 1, an average age of a website is 7 years. In the sample, only $2 \%$ of the websites were general in the sense that they posted any type of a CV or a job opening. Websites that specialized in a particular occupation or industry hosted on average one and two different types of CVs and job postings, respectively. The majority of the websites in the sample $(65 \%)$ served the entire USA while the rest served a state within the USA. Most websites offered career-related information (93\%) and subscription to email alerts of good matches $(80 \%)$. In terms of the attributes of the markets that the websites served, an average website served a market where $68 \%$ of residents had Internet access, $28 \%$ of residents had a college degree, and $2 \%$ of the employed 
Table 2 Growth in online traffic by exposure to Craigslist's presence

\begin{tabular}{|c|c|c|c|c|}
\hline \multirow[t]{4}{*}{ Sample } & \multicolumn{4}{|c|}{ A panel of employment websites (2005/06-2007/08) } \\
\hline & \multicolumn{2}{|c|}{ National websites compete with Craigslist } & \multicolumn{2}{|c|}{$\begin{array}{l}\text { National websites do not compete with } \\
\text { Craigslist }\end{array}$} \\
\hline & $\begin{array}{l}\text { Growth in number } \\
\text { of visitors }\end{array}$ & $\begin{array}{l}\text { Growth in \# of page } \\
\text { views per }\end{array}$ & $\begin{array}{l}\text { Growth in number } \\
\text { of visitors }\end{array}$ & $\begin{array}{l}\text { Growth in \# of page } \\
\text { views per }\end{array}$ \\
\hline & $(1)$ & $(2)$ & (3) & (4) \\
\hline Average website & 0.332 & 1.158 & 0.332 & 1.158 \\
\hline \multicolumn{5}{|c|}{ Exposure: growth of job posts on Craigslist } \\
\hline $\begin{array}{l}95 \% \text { percentile of } \\
\text { exposure }\end{array}$ & 0.190 & 3.909 & -0.825 & 12.271 \\
\hline $\begin{array}{l}5 \% \text { percentile of } \\
\text { exposure }\end{array}$ & 0.563 & 0.156 & -0.134 & 1.499 \\
\hline $\begin{array}{l}75 \% \text { percentile of } \\
\text { exposure }\end{array}$ & 0.912 & 1.032 & 1.133 & 2.119 \\
\hline $\begin{array}{l}25 \% \text { percentile of } \\
\text { exposure }\end{array}$ & 0.958 & 0.821 & -0.022 & 0.160 \\
\hline \multicolumn{5}{|c|}{ Exposure: years of Craigslist presence } \\
\hline $\begin{array}{l}95 \% \text { percentile of } \\
\text { exposure }\end{array}$ & 2.922 & 21.902 & 3.610 & 13.441 \\
\hline $\begin{array}{l}5 \% \text { percentile of } \\
\text { exposure }\end{array}$ & 3.817 & 25.774 & 13.277 & 13.529 \\
\hline $\begin{array}{l}75 \% \text { percentile of } \\
\text { exposure }\end{array}$ & 2.922 & 21.902 & 11.503 & 12.840 \\
\hline $\begin{array}{l}25 \% \text { percentile of } \\
\text { exposure }\end{array}$ & 3.848 & 29.733 & 13.277 & 13.529 \\
\hline
\end{tabular}

worked in the information sector. An average labor market was characterized by $4.9 \%$ unemployment rate and $15.7 \%$ job creation rate.

Table 1 also reports summary statistics for Craigslist's presence as measured by either the number of job-related postings or the number of years of Craigslist's presence for two different treatments of national websites: one coding national websites as competing with Craigslist and the other coding them as not competing with Craigslist. When national websites are coded as competing with Craigslist, Craigslist hosted 909,443 jobrelated postings in an average market and had been present, on average, for 8 years. ${ }^{16}$ When national websites are coded as not competing with Craigslist, Craigslist hosted 5743 job-related postings in an average market and had been present for about 2 years. ${ }^{17}$

\section{Craigslist's impact on online traffic at competing websites}

In Table 2, we report the average growth of online traffic for websites that differ in their exposure to Craigslist. We measure exposure with the growth in the number of job posts on Craigslist in the markets of competing websites or the number of years of Craigslist's presence. We find that the growth in the number of visitors was about one to six times lower (columns 1 and 3 in Table 2) for websites that were most exposed to Craigslist's presence (top five percentile) compared to those that were least exposed to Craigslist's presence (in the bottom five percentile based on either the growth of jobs on Craigslist or the years of Craigslist's presence).$^{18}$ 
The difference in the growth is smaller (between 5 and $32 \%$ ) when we compare employment websites that were more similar to each other in terms of their exposure to Craigslist's presence, i.e., the $25 \%$ most and the $25 \%$ least exposed websites. In one comparison of eight, the difference in the growth of visitors between the most exposed and the least exposed is reversed. ${ }^{19}$ Evidence is more mixed for page views. The growth in the number of page views per visitor was faster for websites that were most exposed to Craigslist's presence compared to those that were least exposed (columns 2 and 4 in Table 2) when exposure is measured with the growth in job posts on Craigslist. When we measure exposure with the years of Craigslist's presence, we find that the most exposed websites hosted between 1 and $36 \%$ fewer page views per visitor compared to the least exposed employment websites.

These preliminary findings suggest that as Craigslist's presence in a market grew, competing employment websites lost online traffic as measured with the number of visitors they attracted. Comparisons that are drawn on the basis of Table 2, however, offer only preliminary observations because they do not account for heterogeneity across markets and competing websites. Table 3 reports estimates of the effects of Craigslist's presence on the online traffic at competing employment websites-specifically, the number of visitors and page views per visitor on competing websites-once we control for observed website-level and market-level heterogeneity. Columns 1 and 2 in Table 3 report evidence for a specification in which national websites are coded as competing with Craigslist. Columns 3 and 4 in Table 3 report evidence for a specification in which national websites do not compete with Craigslist.

Estimates in column 1 reveal that the number of visitors that an average website attracted in a typical month decreased with Craigslist's presence. In particular, for every 100 job postings that Craigslist hosted about 3740 fewer visitors were attracted to an

Table 3 Craigslist entry and online traffic at competing employment websites

\begin{tabular}{|c|c|c|c|c|}
\hline \multirow{3}{*}{$\begin{array}{l}\text { Sample } \\
\text { Treatment of national websites } \\
\text { Dependent variable }\end{array}$} & \multicolumn{4}{|c|}{ A panel of employment websites (2005/06-2007/08) } \\
\hline & \multicolumn{2}{|c|}{$\begin{array}{l}\text { National websites compete with } \\
\text { Craigslist }\end{array}$} & \multicolumn{2}{|c|}{$\begin{array}{l}\text { National websites do not compete } \\
\text { with Craigslist }\end{array}$} \\
\hline & $\begin{array}{l}\text { Number of visitors } \\
\text { (in } 100,000 \text { ) in } \\
\text { a month }\end{array}$ & $\begin{array}{l}\text { Number of page } \\
\text { views per visitor } \\
\text { per visit }\end{array}$ & $\begin{array}{l}\text { Number of visitors } \\
\text { (in 100,000) in } \\
\text { a month }\end{array}$ & $\begin{array}{l}\text { Number of page } \\
\text { views per visitor } \\
\text { per visit }\end{array}$ \\
\hline Measure of exposure & $(1)$ & (2) & (3) & (4) \\
\hline \multirow[t]{2}{*}{ Years since Craigslist's entry } & -5.597 & -19.729 & -5.859 & -23.586 \\
\hline & $(0.340)^{* * *}$ & $(15.101)$ & $(0.357)^{* * *}$ & $(14.079)^{*}$ \\
\hline \multirow{2}{*}{$\begin{array}{l}\text { Number of job ads on Craigslist } \\
\text { (in 1000) }\end{array}$} & -0.374 & -7.390 & -0.274 & -6.649 \\
\hline & $(0.008)^{* * *}$ & $(1.183)^{* * *}$ & $(0.037)^{* * *}$ & $(3.343)^{*}$ \\
\hline Controls: website FE & $\checkmark$ & $\checkmark$ & $\checkmark$ & $\checkmark$ \\
\hline Controls: year FE & $\checkmark$ & $\checkmark$ & $\checkmark$ & $\checkmark$ \\
\hline Controls: website attributes & $\checkmark$ & $\checkmark$ & $\checkmark$ & $\checkmark$ \\
\hline Controls: market attributes & $\checkmark$ & $\checkmark$ & $\checkmark$ & $\checkmark$ \\
\hline Mean of dependent variable & 11.504 & 22.072 & 11.504 & 22.072 \\
\hline Observations & 66 & 126 & 66 & 126 \\
\hline Number of websites & 33 & 63 & 33 & 63 \\
\hline
\end{tabular}


average competing website (column 1 in Table 3). The number of visitors to an average competing employment website decreased by an estimated 559,700 for every additional year Craigslist was present in the market (column 1 in Table 3). The average number of visitors in $2005 / 06$ was $1,037,890$ whereas in $2007 / 08$ it was $1,262,823$. We find a similar pattern when we code websites that serve the entire USA as not competing with Craigslist (column 3 in Table 3).

The average visitor also reviewed fewer pages the longer Craigslist operated in the market and the more postings Craigslist hosted (columns 2 and 4 in Table 3). The average number of page views per visitor at a competing website declined by about 20 for every additional year of Craigslist's presence in the market since its entry (columns 2 and 4 in Table 3). Similarly, for every 100 job postings on Craigslist, the number of page views per visitor that a competing website attracted fell by, on average, 1 (column 2 in Table 3). The average number of page views in 2005/06 was 17 whereas in 2007/08 it was 27. We find a similar pattern when we code national websites as not competing with Craigslist (column 4 in Table 3).

\section{Craigslist's impact on pricing by competing websites}

Our findings thus far indicate that an increase in Craigslist's presence was associated with a decline in online traffic at competing employment websites. This evidence is consistent with the view that the entry of Craigslist cannibalized online traffic at competing employment websites. In this section, we want to check whether a decline in the online traffic was caused by an increase in prices that competing employment websites charged their users rather than a change in competition faced by the websites. According to Table 4, however, the declines in visitors and page views per visitor as Craigslist became more entrenched in local labor markets were accompanied by either a decrease in the fees or no change in the fees.

Specifically, average fees for posting a job ad at competing websites decreased by an estimated \$2.4 per day of posting a job ad (column 1 in Table 4) for every year that the websites faced competition from Craigslist. This estimate is not statistically significant when national websites are coded as not competing with Craigslist (column 4 in Table 4). We find evidence that Craigslist's entry resulted in a drop in a fee by $\$ 28.8$ for a month of access to $\mathrm{CV}$ postings only when national websites are coded as not competing with Craigslist. Craigslist's entry had no effect when these websites were coded as competing with Craigslist (columns 2 and 5 in Table 4). We find no evidence that Craigslist's entry had an effect on the price that the websites charged to job searchers for posting a CV (columns 3 and 6 in Table 4). ${ }^{20}$

We extend our analysis of pricing along two dimensions. First, we check whether websites were more likely to offer a discount (Table 5). In the data, we observe whether discounts were based on the type of a posting (career level, volunteering opportunities, occupation), firm type (nonprofit, government, size), volume (number or duration of postings or access), or membership. We can distinguish whether the discount was offered to employers or to job searchers. We find some evidence that Craigslist's entry increased the likelihood that a discount was offered to both employers and job searchers (columns 1, 2, and 5 in Table 5). For example, the likelihood that a competing website offered a discount to employers and job searchers, respectively, increased by 8 and $7 \%$ for every 100 job postings that Craigslist hosted (columns 1 and 2 in Table 5). Hence, 
Table 4 Craigslist entry and pricing by competing employment websites

\begin{tabular}{|c|c|c|c|c|c|c|}
\hline \multirow{3}{*}{$\begin{array}{l}\text { Sample } \\
\text { Dependent variable }\end{array}$} & \multicolumn{6}{|c|}{ A panel of employment websites (2005/06-2007/08) } \\
\hline & \multicolumn{3}{|c|}{ National websites compete with Craigslist } & \multicolumn{3}{|c|}{$\begin{array}{l}\text { National websites do not compete with } \\
\text { Craigslist }\end{array}$} \\
\hline & $\begin{array}{l}\text { Fee for a } \\
\text { day of job } \\
\text { posting (\$) }\end{array}$ & $\begin{array}{l}\text { Fee for a } \\
\text { month of access } \\
\text { to CVs (\$) }\end{array}$ & $\begin{array}{l}\text { Fee for a } \\
\text { day of CV } \\
\text { posting (\$) }\end{array}$ & $\begin{array}{l}\text { Fee for a } \\
\text { day of job } \\
\text { posting (\$) }\end{array}$ & $\begin{array}{l}\text { Fee for a } \\
\text { month of } \\
\text { access to CVs (\$) }\end{array}$ & $\begin{array}{l}\text { Fee for a } \\
\text { day of CV } \\
\text { posting (\$) }\end{array}$ \\
\hline Measure of exposure & $(1)$ & $(2)$ & $(3)$ & $(4)$ & $(5)$ & $(6)$ \\
\hline \multirow{2}{*}{$\begin{array}{l}\text { Years since Craigslist's } \\
\text { entry }\end{array}$} & -2.413 & -254.741 & -0.002 & -0.033 & -35.228 & 0.001 \\
\hline & $(1.515)^{*}$ & $(199.591)$ & $(0.010)$ & $(0.160)$ & $(56.968)$ & $(0.002)$ \\
\hline \multirow{2}{*}{$\begin{array}{l}\text { Number of job ads on } \\
\text { Craigslist (in 1000) }\end{array}$} & 0.009 & 75.921 & 0.000 & 0.044 & $-28.840^{* * *}$ & 0.000 \\
\hline & $(0.072)$ & $(60.719)$ & $(0.001)$ & $(0.036)$ & $(2.152)$ & $(0.000)$ \\
\hline Controls: website FE & $\checkmark$ & $\checkmark$ & $\checkmark$ & $\checkmark$ & $\checkmark$ & $\checkmark$ \\
\hline Controls: year FE & $\checkmark$ & $\checkmark$ & $\checkmark$ & $\checkmark$ & $\checkmark$ & $\checkmark$ \\
\hline $\begin{array}{l}\text { Controls: website } \\
\text { attributes }\end{array}$ & $\checkmark$ & $\checkmark$ & $\checkmark$ & $\checkmark$ & $\checkmark$ & $\checkmark$ \\
\hline $\begin{array}{l}\text { Controls: market } \\
\text { attributes }\end{array}$ & $\checkmark$ & $\checkmark$ & $\checkmark$ & $\checkmark$ & $\checkmark$ & $\checkmark$ \\
\hline $\begin{array}{l}\text { Mean of dependent } \\
\text { variable }\end{array}$ & 3.363 & 263.992 & 0.003 & 3.363 & 263.992 & 0.003 \\
\hline Observations & 180 & 82 & 184 & 180 & 82 & 184 \\
\hline Number of websites & 90 & 41 & 92 & 90 & 41 & 92 \\
\hline
\end{tabular}

Standard errors clustered at the market level in parentheses

*significant at $10 \%$; **significant at $5 \%$; ${ }^{* * *}$ significant at $1 \%$

while we find some evidence that Craigslist's entry caused a decline in the listed prices, this evidence is not robust to different treatment of national websites. Nevertheless, our follow-up analysis of the provision of discounts suggests that it is likely that the prices that were actually paid by the users of employment websites fell with Craigslist's entry as discounts for both employers and job searchers became more prevalent.

Second, we check whether websites were more likely to bundle together services that they offered to employers. Specifically, we observe whether employers were granted free access to CVs whenever they paid a fee for a job posting. We speculate that such bundling of the two services might become more likely as competition intensifies as a way to secure participation on a platform. We find, however, no evidence that the websites were more likely to bundle access to CVs and posting of a job ad (columns 3 and 6 in Table 5).

\section{Robustness checks}

Measurement of Craigslist's presence: We used the number of cities within each state that Craigslist entered as an alternative measure of Craigslist's presence while controlling for population size and population density. The estimates from this alternative specification are reported in Table 6. We find evidence that a greater Craigslist's presence reduced the number of visitors to competing employment websites. No effect is found of Craigslist's presence on either competing websites' pricing or the number of page views per visitor.

Sample period: Our analysis is restricted to a period from 2005 to 2007. This restriction is motivated by several factors that we review in our description of our empirical 
Table 5 Craigslist entry and pricing by competing employment websites

\begin{tabular}{|c|c|c|c|c|c|c|}
\hline \multirow{3}{*}{$\begin{array}{l}\text { Sample } \\
\text { Dependent variable }\end{array}$} & \multicolumn{6}{|c|}{ A panel of employment websites (2005/06-2007/08) } \\
\hline & \multicolumn{3}{|c|}{ National websites compete with Craigslist } & \multicolumn{3}{|c|}{$\begin{array}{l}\text { National websites do not compete with } \\
\text { Craigslist }\end{array}$} \\
\hline & $\begin{array}{l}1 \text { if discount } \\
\text { offered to } \\
\text { employers }\end{array}$ & $\begin{array}{l}1 \text { if discount } \\
\text { offered to } \\
\text { job searchers }\end{array}$ & $\begin{array}{l}1 \text { if bundling } \\
\text { of CV access } \\
\text { and job } \\
\text { posting } \\
\text { offered }\end{array}$ & $\begin{array}{l}1 \text { if discount } \\
\text { offered to } \\
\text { employers }\end{array}$ & $\begin{array}{l}1 \text { if discount } \\
\text { offered to } \\
\text { job searchers }\end{array}$ & $\begin{array}{l}1 \text { if bundling } \\
\text { of } C V \text { access } \\
\text { and job } \\
\text { posting } \\
\text { offered }\end{array}$ \\
\hline $\begin{array}{l}\text { Measure of } \\
\text { exposure }\end{array}$ & (1) & $(2)$ & (3) & (4) & (5) & (6) \\
\hline \multirow{2}{*}{$\begin{array}{l}\text { Years since } \\
\text { Craigslist's entry }\end{array}$} & 0.106 & -0.053 & 0.315 & -0.007 & 0.011 & -0.022 \\
\hline & $(0.410)$ & $(0.036)$ & $(0.349)$ & $(0.050)$ & $(0.006)^{*}$ & $(0.026)$ \\
\hline \multirow{2}{*}{$\begin{array}{l}\text { Number of job ads } \\
\text { on Craigslist (in } \\
\text { 1000) }\end{array}$} & 0.036 & 0.002 & -0.027 & -0.082 & 0.002 & -0.016 \\
\hline & $(0.007)^{* * *}$ & $(0.001)^{*}$ & $(0.018)$ & $(0.097)$ & $(0.001)^{*}$ & $(0.013)$ \\
\hline $\begin{array}{l}\text { Controls: website } \\
\text { FE }\end{array}$ & $\checkmark$ & $\checkmark$ & $\checkmark$ & $\checkmark$ & $\checkmark$ & $\checkmark$ \\
\hline Controls: year FE & $\checkmark$ & $\checkmark$ & $\checkmark$ & $\checkmark$ & $\checkmark$ & $\checkmark$ \\
\hline $\begin{array}{l}\text { Controls: website } \\
\text { attributes }\end{array}$ & $\checkmark$ & $\checkmark$ & $\checkmark$ & $\checkmark$ & $\checkmark$ & $\checkmark$ \\
\hline $\begin{array}{l}\text { Controls: market } \\
\text { attributes }\end{array}$ & $\checkmark$ & $\checkmark$ & $\checkmark$ & $\checkmark$ & $\checkmark$ & $\checkmark$ \\
\hline $\begin{array}{l}\text { Mean of dependent } \\
\text { variable }\end{array}$ & 0.440 & 0.027 & 0.314 & 0.440 & 0.027 & 0.314 \\
\hline Observations & 116 & 188 & 188 & 116 & 188 & 188 \\
\hline $\begin{array}{l}\text { Number of } \\
\text { websites }\end{array}$ & 58 & 94 & 94 & 58 & 94 & 94 \\
\hline
\end{tabular}

Standard errors clustered at the market level in parentheses

*significant at $10 \%$; ${ }^{* *}$ significant at $5 \%$; ${ }^{* * *}$ significant at $1 \%$

approach. We expanded the sample to include years prior to 2005 (Weddle, 2000, 2001, 2002, 2003, 2004). We report the results in Table 7. In general, we find that fewer estimates are statistically significant. This is consistent with some of the concerns that we raised about extending our analysis beyond the 2-year period that is the focus of most of our estimates, most notably, the fact that Craigslist became a large player only in 2005 (Kroft and Pope, 2014). Because our sample extension includes years prior to 2005, the estimates pertain to the effects of Craigslist's entry in markets during the times when Craigslist was too small to matter.

That said, we do find several statistically significant estimates. These estimates suggest, for example, that an additional year of Craigslist's presence in a market was associated with a decrease in the number of average page views per visitor by three (column 2), an increase by 1 percentage point in the likelihood that job searchers were offered a discount (column 7), and a decrease by 46 percentage points in the likelihood that employers were offered a discount (column 6). One thousand additional job ads on Craigslist were linked to a decline in the fee for access to CVs by $\$ 2$ per month of access (column 4). These estimates tend to be sensitive to whether or not we code national websites to be competing with Craigslist. 
Table 6 Alternative measure of exposure to Craigslist

\begin{tabular}{|c|c|c|c|c|c|c|c|c|}
\hline \multirow{3}{*}{$\begin{array}{l}\text { Sample } \\
\text { Dependent } \\
\text { variable }\end{array}$} & \multicolumn{8}{|c|}{ Unbalanced panel of employment websites (2005/06-2007/08) } \\
\hline & $\begin{array}{l}\text { Number of } \\
\text { visitors } \\
\text { (in 100,000) } \\
\text { in a month }\end{array}$ & $\begin{array}{l}\text { Number of } \\
\text { page views } \\
\text { per visitor } \\
\text { per visit }\end{array}$ & $\begin{array}{l}\text { Fee for a } \\
\text { day of job } \\
\text { posting }(\$)\end{array}$ & $\begin{array}{l}\text { Fee for a } \\
\text { month of } \\
\text { access to } \\
\text { CVs (\$) }\end{array}$ & $\begin{array}{l}\text { Fee for } \\
\text { a day } \\
\text { of CV } \\
\text { posting } \\
\text { (\$) }\end{array}$ & $\begin{array}{l}1 \text { if } \\
\text { discount } \\
\text { offered to } \\
\text { employers }\end{array}$ & $\begin{array}{l}1 \text { if } \\
\text { discount } \\
\text { offered to } \\
\text { job } \\
\text { searchers }\end{array}$ & $\begin{array}{l}1 \text { if bundling } \\
\text { of CV access } \\
\text { and job } \\
\text { posting } \\
\text { offered }\end{array}$ \\
\hline & $(1)$ & $(2)$ & (3) & (4) & $(5)$ & $(6)$ & (7) & (8) \\
\hline \multicolumn{9}{|c|}{$\begin{array}{l}\text { Specification: national websites } \\
\text { compete with Craigslist }\end{array}$} \\
\hline \multirow{2}{*}{$\begin{array}{l}\text { \# of cities } \\
\text { with } \\
\text { Craigslist's } \\
\text { presence }\end{array}$} & -2.100 & -0.001 & -0.000 & 0.247 & -0.000 & 0.000 & -0.000 & 0.000 \\
\hline & $(0.050)^{* * *}$ & $(0.217)$ & $(0.001)$ & $(0.692)$ & $(0.000)$ & $(0.000)$ & $(0.000)$ & $(0.000)$ \\
\hline \multicolumn{9}{|c|}{$\begin{array}{l}\text { Specification: national websites do not compete } \\
\text { with Craigslist }\end{array}$} \\
\hline \multirow{2}{*}{$\begin{array}{l}\text { \# of cities } \\
\text { with } \\
\text { Craigslist's } \\
\text { presence }\end{array}$} & -8.683 & -7.398 & 0.067 & 7.583 & 0.000 & 0.152 & 0.003 & -0.037 \\
\hline & $(0.066)^{* * *}$ & $(3.598)^{*}$ & $(0.158)$ & $(31.174)$ & $(0.001)$ & $(0.135)$ & $(0.004)$ & $(0.047)$ \\
\hline $\begin{array}{l}\text { Controls: } \\
\text { website FE }\end{array}$ & $\checkmark$ & $\checkmark$ & $\checkmark$ & $\checkmark$ & $\checkmark$ & $\checkmark$ & $\checkmark$ & $\checkmark$ \\
\hline $\begin{array}{l}\text { Controls: } \\
\text { year FE }\end{array}$ & $\checkmark$ & $\checkmark$ & $\checkmark$ & $\checkmark$ & $\checkmark$ & $\checkmark$ & $\checkmark$ & $\checkmark$ \\
\hline $\begin{array}{l}\text { Controls: } \\
\text { website } \\
\text { attributes }\end{array}$ & $\checkmark$ & $\checkmark$ & $\checkmark$ & $\checkmark$ & $\checkmark$ & $\checkmark$ & $\checkmark$ & $\checkmark$ \\
\hline $\begin{array}{l}\text { Controls: } \\
\text { market } \\
\text { attributes }\end{array}$ & $\checkmark$ & $\checkmark$ & $\checkmark$ & $\checkmark$ & $\checkmark$ & $\checkmark$ & $\checkmark$ & $\checkmark$ \\
\hline $\begin{array}{l}\text { Mean of } \\
\text { dependent } \\
\text { variable }\end{array}$ & 11.504 & 22.072 & 3.363 & 263.992 & 0.003 & 0.440 & 0.027 & 0.314 \\
\hline Observations & 66 & 126 & 180 & 82 & 184 & 116 & 188 & 188 \\
\hline $\begin{array}{l}\text { Number of } \\
\text { websites }\end{array}$ & 33 & 63 & 90 & 41 & 92 & 58 & 94 & 94 \\
\hline
\end{tabular}

Standard errors clustered at the market level in parentheses *significant at $10 \%$; ${ }^{* *}$ significant at $5 \%$; ${ }^{* *}$ significant at $1 \%$

\section{Conclusions}

We find that Craigslist's entry into a local labor market was associated with a decrease in the number of visitors and page views per visitor at competing employment websites. This finding speaks to evidence in Kroft and Pope (2014) that Craigslist entry had no effect on the unemployment rate in local labor markets. Consistent with Kroft and Pope's proposed explanation for their null result (p. 298), our finding suggests that Craigslist's entry had a muted effect on local labor markets, in part, because Craigslist cannibalized online traffic at competing websites that offered similar services at the time of Craigslist's entry.

We also observe that websites reacted to increased competition prompted by Craigslist's entry by decreasing some of the fees that they charged to their users. Overall, these findings suggest that Craigslist's entry might have had mixed welfare effects. Increased competition and the resulting reduction in prices prompted by the entry likely benefitted participants in these markets. At the same time, however, Craigslist's entry 
Table 7 Extension of the sample period (2000 through 2007)

\begin{tabular}{|c|c|c|c|c|c|c|c|c|}
\hline \multirow{3}{*}{$\begin{array}{l}\text { Sample } \\
\text { Dependent } \\
\text { variable }\end{array}$} & \multicolumn{8}{|c|}{ Unbalanced panel of employment websites (2000-2007/08) } \\
\hline & $\begin{array}{l}\text { Number of } \\
\text { visitors (in } \\
100,000 \text { ) } \\
\text { in a month }\end{array}$ & $\begin{array}{l}\text { Number of } \\
\text { page views } \\
\text { per visitor } \\
\text { per visit }\end{array}$ & $\begin{array}{l}\text { Fee for } \\
\text { a day } \\
\text { of job } \\
\text { posting } \\
\text { (\$) }\end{array}$ & $\begin{array}{l}\text { Fee for a } \\
\text { month of } \\
\text { access to } \\
\text { CVs }(\$)\end{array}$ & $\begin{array}{l}\text { Fee for } \\
\text { a day } \\
\text { of CV } \\
\text { posting } \\
(\$)\end{array}$ & $\begin{array}{l}1 \text { if } \\
\text { discount } \\
\text { offered to } \\
\text { employers }\end{array}$ & $\begin{array}{l}1 \text { if } \\
\text { discount } \\
\text { offered to } \\
\text { job } \\
\text { searchers }\end{array}$ & $\begin{array}{l}1 \text { if bundling } \\
\text { of } C V \text { access } \\
\text { and job } \\
\text { posting } \\
\text { offered }\end{array}$ \\
\hline & $(1)$ & $(2)$ & (3) & (4) & $(5)$ & $(6)$ & (7) & $(8)$ \\
\hline \multicolumn{9}{|c|}{$\begin{array}{l}\text { Specification: national websites } \\
\text { compete with Craigslist }\end{array}$} \\
\hline \multirow{2}{*}{$\begin{array}{l}\text { Years since } \\
\text { Craigslist's } \\
\text { entry }\end{array}$} & 5.016 & 4.076 & 1.230 & 104.697 & 0.003 & -0.463 & 0.008 & -0.081 \\
\hline & $(5.674)$ & $(4.023)$ & $(0.912)$ & $(101.912)$ & $(0.004)$ & $(0.191)^{* *}$ & $(0.013)$ & $(0.076)$ \\
\hline \multirow{2}{*}{$\begin{array}{l}\text { Number of } \\
\text { jobs ads } \\
\text { on } \\
\text { Craigslist } \\
\text { (in 1000) }\end{array}$} & 0.088 & 0.042 & -0.064 & -2.184 & -0.000 & -0.001 & 0.000 & -0.002 \\
\hline & $(0.081)$ & $(0.154)$ & $(0.045)$ & $(1.244)^{*}$ & $(0.000)^{* * *}$ & $(0.001)$ & $(0.000)$ & $(0.003)$ \\
\hline \multicolumn{9}{|c|}{$\begin{array}{l}\text { Specification: national websites do not compete } \\
\text { with Craigslist }\end{array}$} \\
\hline \multirow{2}{*}{$\begin{array}{l}\text { Years since } \\
\text { Craigslist's } \\
\text { entry }\end{array}$} & 3.237 & -2.756 & -0.863 & 37.842 & -0.000 & 0.031 & 0.008 & -0.072 \\
\hline & $(2.252)$ & $(1.182)^{* *}$ & $(0.889)$ & (55.191) & $(0.001)$ & $(0.078)$ & $(0.005)^{*}$ & $(0.046)$ \\
\hline \multirow{2}{*}{$\begin{array}{l}\text { Number of } \\
\text { jobs ads } \\
\text { on } \\
\text { Craigslist } \\
\text { (in 1000) }\end{array}$} & 0.501 & -0.391 & 0.014 & 37.943 & 0.000 & 0.019 & 0.000 & -0.010 \\
\hline & $(0.335)$ & $(0.456)$ & $(0.102)$ & $(25.464)$ & $(0.000)$ & $(0.016)$ & $(0.001)$ & $(0.007)$ \\
\hline $\begin{array}{l}\text { Mean of } \\
\text { dependent } \\
\text { variable }\end{array}$ & 9.210 & 16.840 & 4.042 & 240.086 & 0.004 & 0.548 & 0.040 & 0.246 \\
\hline Observations & 231 & 547 & 603 & 314 & 344 & 465 & 353 & 643 \\
\hline
\end{tabular}

Standard errors clustered at the market level in parentheses

*significant at $10 \%$; ${ }^{* *}$ significant at $5 \%$; ${ }^{* *}$ significant at $1 \%$. Controls: see Table 3

rendered each existing competing website less thick and thus less valuable to individual users. In a broader sense, our findings reveal the difficulties (a) of evaluating the impact of diffusion of the Internet on activities offline when diffusion is measured with an entry of a single online entity such as Craigslist and (b) with translating improvements in search technologies into more efficient labor markets.

\section{Endnotes}

${ }^{1}$ By contrast, Kroft and Pope (2014) find that Craigslist's entry reduced vacancy rates in the real-estate rental markets where online alternatives to Craigslist were few.

${ }^{2}$ An alternative explanation proposed by Kroft and Pope (2014) attributes their null result to a possibility that the gains of using Craigslist are small because of small search frictions and negligible information asymmetry in the US labor market.

${ }^{3}$ Some examples of platforms that operate in multi-sided markets include sports card conventions that facilitate interactions between buyers and sellers of sports cards (Jin and Rysman (2014)), newspapers that facilitate interactions between readers and 
advertisers (Chandra and Collard-Wexler (2009), Fan (2013), and Seamans and Zhu (2014)), and employment websites that facilitate interactions between employers with job vacancies and job searchers.

${ }^{4}$ Jin and Rysman (2014) focus on pricing by organizers of sports card conventions. Chandra and Collard-Wexler (2009) examine pricing and circulation in a market for newspapers. Fan (2013) and Seamans and Zhu (2014) look at pricing, circulation, and product attributes in a market for newspapers.

${ }^{5}$ Brenčič (2014) uses the same source of data to examine a link between the number of pages a typical visitor to employment websites reviews and the number of postings that are available for a review.

${ }^{6}$ According to the Guides, $40 \%$ of the surveyed websites in each survey changed from one survey to the next. Because the goal of the Guides is to report on the leading employment websites and websites that offer novel features, large websites are the most likely to be represented in our sample.

${ }^{7}$ We define a relevant labor market at the level of a state because that is the level for which competing employment websites' markets are observed in the data. Kroft and Pope (2014) define the market at the MSA level whereas Seamans and Zhu (2014) define the relevant market at the county level. Chan and Ghose (2014) define the market at the state level and at the county level for four US states and NYC.

${ }^{8}$ In the samples that we used to get our estimates, between 63 and $80 \%$ of the websites served the entire USA. This is consistent with the fact that our sample overrepresents large employment websites. These websites are more likely to remain active over the period during which the two Weddle surveys were conducted and are more likely to be included in each of the two Weddle surveys.

${ }^{9}$ Kroft and Pope (2014, p. 261) note that the number of job-related posts on Craigslist for major metropolitan areas represented two thirds of the total number of posts for the areas on three large employment websites that serve the entire US market: Monster, CareerBuilder, and Yahoo! Hotjobs.

${ }^{10}$ It is possible, however, that requests for Craigslist's entry come from markets where many employment websites offer services but, unlike Craigslist, charge high fees for their services. In most markets, Craigslist does not charge for its services.

${ }^{11} \mathrm{Kroft}$ and Pope (2014, p. 273) note that the number of posts was nearly zero in most cities but for a select few larger cities.

${ }^{12}$ The data were collected from a website that archives old snapshots of websites (http://archive.org). When data on more than one date were available, we chose a date in the last quarter of a year. If Craigslist was present in multiple cities in a state, we summed the number of posts across all the cities.

${ }^{13}$ Data for 2009 were assigned to the $2007 / 2008$ survey, and data for 2007 to the 2005/2006 survey.

${ }^{14}$ The data were acquired from the Census Bureau and the Bureau of Labor Statistics.

${ }^{15}$ The sample is restricted to websites that are surveyed in both Guides. Nevertheless, the size of the sample varies across statistics because different websites have missing values for different variables.

${ }^{16}$ In other words, the variable for Craigslist's presence is assigned the sum of jobrelated posts on Craigslist aggregated across all of Craigslist's locations in the USA. 
${ }^{17}$ In other words, we set the number of posts on Craigslist equal to zero for observations from websites that served the entire USA.

${ }^{18}$ We report a range because of two treatments of employment websites that serve the entire USA, i.e., in one treatment these websites are coded not to compete with Craigslist while in the other treatment they are coded to compete with Craigslist.

${ }^{19}$ This reversed pattern occurs for the following: when exposure is measured with the growth of job posts on Craigslist, we compare the $25 \%$ most and the $25 \%$ least exposed websites, and when websites that serve the entire USA are coded as not competing with Craigslist.

${ }^{20}$ Given that a majority did not charge a fee for a posting of a $\mathrm{CV}$, we think that insufficient variation in the dependent variable can explain statistically insignificant effects in columns 3 and 6 in Table 4.

\section{Competing interest}

The IZA Journal of Labor Economics is committed to the IZA Guiding Principles of Research Integrity. The author declares that she has observed these principles.

\section{Acknowledgements}

I would like to thank the editor and the anonymous referee for the useful remarks.

Responsible editor: Pierre Cahuc

Received: 3 March 2016 Accepted: 29 May 2016

Published online: 28 June 2016

References

Agrawal AK, Lacetera N, Lyons E (2013) Does information help or hinder job applicants from less developed countries in online markets, NBER working paper 18720

Autor D (2001) Wiring the labor market. J Econ Perspect 15:25-40

Brenčič V (2014) Search online: evidence from information acquisition at online job boards and resume banks. J Econ Psychol 42:112-125

Brenčič V, Norris JB (2010) Do employers change job offers in their online job ads to facilitate search? Econ Lett 108:46-48

Chan J, Ghose A (2014) Internet's dirty secret: assessing the impact of online intermediaries on HIV transmission. MIS Q 38:955-976

Chandra A, Collard-Wexler A (2009) Mergers in two-sided markets: an application to the Canadian newspaper industry. J Econ Manag Strateg 18:1045-1070

Fan Y (2013) Ownership consolidation and product characteristics: a study of the U.S. daily newspaper market. Am Econ Rev 103:1598-1628

Gurun UG, Butler AW (2012) Don't believe the hype: local media slant, local advertising, and firm value. J Financ 67: $561-597$

Horton JJ (2016) The effects of algorithmic labor market recommendations: evidence from a field experiment, working paper Jin GZ, Rysman M (2015) Platform pricing at sports-card conventions. J Ind Econ 63:704-735

Kroft K, Pope DG (2014) Does online search crowd out traditional search and improve matching efficiency? Evidence from Craigslist. J Labor Econ 32:259-303

Kudlyak M, Lkagvasuren D, Sysuyev R (2013) Systematic job search: new evidence from individual job application data. Working paper

Marinescu I, Rathelot R (2014) Mismatch unemployment and geography of search. Working paper

Pallais A (2014) Inefficient hiring in entry-level labor markets. Am Econ Rev 104:3565-3599

Seamans R, Zhu F (2014) Responses to entry in multi-sided markets: the impact of Craigslist on local newspapers. Manag Sci 60:476-493

Stanton C, Thomas C (2015) Landing the first job: the value of Intermediaries in online hiring. Rev Econ Stud. http://restud.oxfordjournals.org/content/early/2015/11/26/restud.rdv042.abstract

Weddle P (2000) Weddle's guide to employment web sites. American Management Association, New York Weddle P (2001) Weddle's guide to employment web sites. American Management Association, New York Weddle P (2002) Weddle's guide to employment web sites. American Management Association, New York Weddle P (2003) Weddle's guide to employment web sites. American Management Association, New York Weddle P (2004) Weddle's guide to employment web sites. American Management Association, New York Weddle P (2005) Weddle's guide to employment sites on the Internet. American Management Association, New York Weddle P (2007) Weddle's guide to employment sites on the Internet. American Management Association, New York 